International Journal of Social Science And Human Research

ISSN(print): 2644-0679, ISSN(online): 2644-0695

Volume 04 Issue 12 December 2021

DOI: $10.47191 / \mathrm{ijsshr} / \mathrm{v} 4-\mathrm{i} 12-35$, Impact factor-5.586

Page No: 3704-3708

\title{
Constraints by the Public Prosecutor in Proving Aspects of Criminal Liability for Narcotics Criminals with Undercover Buy Techniques
}

\author{
Trynalia $^{1}$, Slamet Tri Wahyudi ${ }^{2}$ \\ ${ }^{1,2}$ Faculty of Law, Universitas Pembangunan Nasional Veteran Jakarta, Indonesia
}

\begin{abstract}
Narcotics crime is one of the extraordinary crimes. In addition to the negative impact it causes, the disclosure of narcotics crimes is not easy because it is transnational in nature, is carried out in secret, organized, uses various modus operandi and uses advanced technology. Therefore, the Law on Narcotics regulates investigative techniques that can be used to uncover narcotics crimes, one of which is an undercover buy investigation technique. However, this technique sometimes also leaves its own problems in its implementation. The objective of this study is to identify and explain the various constraints faced by the Public Prosecutor in proving aspects of criminal responsibility for narcotics criminals, especially those carried out with the undercover buy technique. This paper using a normative research type through a statutory approach and a case approach. This study explains that the Public Prosecutor still has problems in proving aspects of criminal responsibility for narcotics criminals, both from internal and external factors. The constraints from internal factors was that the Public Prosecutor was not careful in checking the completeness of the formal. Meanwhile, external factors, namely investigators did not provide actual information regarding the completeness of the material submitted in the first stage of file submission. Therefore, it is necessary to improve the regulation and coordination between law enforcement officers in terms of proving the accountability aspects of narcotics criminals using undercover buy techniques.
\end{abstract}

KEYWORDS: Undercover Buy, Narcotics Crime, Criminal Liability

\section{INTRODUCTION}

Narcotics are substances or drugs that are very useful and necessary for the treatment of certain diseases. However, if it is misused or used not in accordance with treatment standards, it can have very detrimental consequences for individuals or society, especially the younger generation. ${ }^{1}$

Law Number 35 of 2009 concerning Narcotics regulates narcotics abuse and narcotics crimes. Disclosure of narcotics crimes is not easy because it is transnational (cross-country), carried out in secret, organized, using various modus operandi and advanced technology. Therefore, the Law on Narcotics regulates investigative techniques that can be used to uncover narcotics crimes. One of them is the technique of investigating undercover buy and submissions under supervision or also known as undercover buy, as regulated in Article 75 letter $j$ of the Act a quo.

This study focuses on the constraints faced by the Public Prosecutor in proving aspects of criminal responsibility for narcotics criminals, especially those carried out with the undercover buy technique. The previous studies that have been carried out are, Undercover Buy Techniques in Narcotics Crime Investigation ${ }^{2}$, Undercover Buy as a strategy for disclosing drug crimes (Juridical-Empirical Study in Pontianak City) ${ }^{3}$, and the Role of Prosecutors in Handling Narcotics Offenders (Case Study on The Misuse of Narcotics Category I Handled by the Semarang City District Attorney) ${ }^{4}$.

In a series of activities before and until an undercover buy is made, sometimes inquirers or investigators commit criminal acts to achieve successful disclosure of narcotics dealer networks. Regarding the crime committed, it is permissible as long as it meets the requirements, namely it must be in a state of urgency or really must be carried out and in its implementation it must be known and approved by their leader. In addition, investigators are also given the authority to take action according to their own

${ }^{1}$ The First Paragraph of General Explanation of Law Number 35 of 2009 on the Narcotics.

2 Sapto Winengku and Umar Ma'ruf, Teknik Pembelian Terselubung Dalam Penyidikan Tindak Pidana Narkotika (Jurnal Hukum Khaira Ummah Vol. 12 No.4 Desember 2017).

${ }^{3}$ Dhani Catra Nugraha, Pembelian Terselubung (Undercover Buy) sebagai strategi pengungkapan kejahatan Narkoba (Studi Yuridis-Empiris di Kota Pontianak), (Jurnal Nestor Magister Hukum, 2016)

${ }^{4}$ Andita Rizkianto, Peran Jaksa Dalam Penanganan Pelaku Tindak Pidana Narkotika (Studi Kasus Penyalahgunaan Narkotika Golongan I Yang Ditangani Oleh Kejaksaan Negeri Kota Semarang, (Jurnal Hukum Khaira Ummah Vol. 12. No. 3 September 2017).

IJSSHR, Volume 04 Issue 12 December 2021

www.ijsshr.in

Page 3704 


\section{Constraints by the Public Prosecutor in Proving Aspects of Criminal Liability for Narcotics Criminals with Undercover Buy Techniques}

judgment based on the provisions of Article 7 paragraph (1) letter j of Law Number 8 of 1981 concerning the Criminal Procedure Code (KUHAP) and Article 18 of Law Number 2 of 2002 concerning the State Police of Republic of Indonesia. ${ }^{5}$

Undercover buy techniques are prone to abuse. Investigators may trap someone by ordering them to make undercover buy and/or supervised surrenders and then make arrests. For this reason, it is necessary to have regulations that limit the undercover buy and/or delivery of narcotics crime investigations. For example, undercover buy can only be made by the investigators themselves and prohibit the acceptance of members of the public. ${ }^{6}$

Disclosure of crimes with undercover buy techniques usually ends with the arrest of the perpetrator in a state caught redhanded with evidence so it is easier to prove the guilt of the perpetrator. However, there are also cases that have been successfully uncovered through undercover buy techniques, after going through the trial process and ending with a decision to be free from all lawsuits (ontslag van rechts-vervolging). One example of this case was tried at the Tangerang District Court with case register Number: 73/Pid.Sus/2019/PN.Tng on behalf of the Defendant Risky Yolanda Binti Yun Wahyudi.

The Public Prosecutor has an important role in proving the wrongdoing to the perpetrator based on the research of the case file at the pre-prosecution stage and then compiling an indictment. In the prosecution stage, he is given the opportunity by the Panel of Judges to prove the defendant's guilt during the trial by presenting witnesses, experts, letters, the defendant, so that they get the evidences that the defendant is guilty and must be held accountable for his/her actions.

Based on these conditions, the researcher was interested in writing and researching about the contraints faced by the Public Prosecutor in terms of proving the aspect of criminal responsibility for narcotics criminals carried out by undercover buy techniques. This research is based on cases as previously mentioned with the hope that in the future the Public Prosecutor will be more careful in handling narcotics crime cases, especially those uncovered by undercover buy techniques.

\section{RESEARCH METHOD}

This research is a normative legal research conducted by selecting library materials or secondary data ${ }^{7}$. There are several approaches in legal research. With this approach, researcher will get information from various aspects regarding the issue that is being tried to find the answers. The approaches used in legal research are the statute approach, the case approach, the historical approach, the comparative approach, and the conceptual approach. ${ }^{8}$ The researcher in this study uses several approaches, namely the statute approach and the case approach.

\section{DISCUSSION}

\section{A. Handling of Narcotics Crime Cases Revealed by Undercover Buy Techniques by the Public Prosecutor}

The disclosure of perpetrators of narcotics crimes using undercover buy techniques makes it easier for the Public Prosecutor to prove the perpetrators' faults before the trial. This is because of the involvement of investigators in legal events as witnesses who saw, heard and experienced firsthand, the existence of evidence that was in the control of the perpetrators or at least directly known stored by the perpetrators and the perpetrators who were caught red-handed so it was not difficult to convince the Panel of Judges to make a decision that the perpetrator is proven guilty and can be punished.

One of the narcotics crime cases that uses covert purchasing techniques is the narcotics crime case on behalf of Risky Yolanda Binti Yun Wahyudi. In handling the case, starting from the pre-prosecution stage, the Public Prosecutor receives and examines the case file from the Investigator. After being scrutinized, the case file is declared complete and ready to be transferred to the District Court for the prosecution stage.

After the case files have been transferred to the District Court, the trial process will continue by presenting evidence in the form of witness statements, letters, and statements from the defendant. In the evidentiary process, new facts were revealed, it turned out that the defendant was an informant from the police officers who arrested her and the defendant was secured along with evidence in the form of methamphetamine after being ordered to buy methamphetamine by the police officer. The facts regarding this informant were never explained in the minutes of examination of the witnesses and suspects in the case file.

The disclosure of the defendant as an informant formed the judge's belief that there was no mistake in the defendant as a narcotics criminal, so that in its decision, the Panel of Judges actually handed down a verdict of acquittal of all lawsuits (onslag van alle rechtsvervolging). ${ }^{9}$ The judge handed down a verdict of acquittal of all lawsuits (onslag van alle

\footnotetext{
${ }^{5}$ Dhani Catra Nugraha, Op.Cit., page 10.

${ }^{6}$ Sapto Winengku dan Umar Ma'ruf, Op.Cit., 10.

${ }^{7}$ Maria S.W. Sumardjono, Bahan Kuliah Metodologi Penelitian Ilmu Hukum, (Yogyakarta: Universitas Gadjah Mada, 2014 ), page 17.

${ }^{8}$ Peter Mahmud Marzuki, Penelitian Hukum: Edisi Revisi, (Jakarta: Kencana, 2013), page 133.

${ }^{9}$ Look again at the provisions of Article 191 paragraph (2) of the Criminal Procedure Code which states "If the Court is of the opinion that the act that has been charged against the Defendant is proven, but the act does not constitute a criminal act, then the Defendant is dismissed from all legal charges."
} 


\section{Constraints by the Public Prosecutor in Proving Aspects of Criminal Liability for Narcotics Criminals with Undercover Buy Techniques}

rechtsvervolging) with the consideration that the Defendant Risky Yolanda Binti Yun Wahyudi was an informant so that she was only a helpless tool from the person who ordered who was seen as the direct perpetrator of the crime and the Defendant Risky Yolanda Binti Yun Wahyudi as a material perpetrator cannot be held criminally responsible because there is a justification for her actions. ${ }^{10}$

Referring to the considerations in the verdict above, the judge chooses the reasons for justification so that they give a verdict of acquittal of all lawsuits (onslag van alle rechtsvervolging). However, they did not explain in their consideration of the Article related to the justification that was used as the basis for making a verdict of acquittal of all lawsuits (onslag van alle rechtsvervolging).

\section{B. s by the Public Prosecutor in Proving Aspects of Criminal Liability for Narcotics Offenders Revealed by Undercover Buy Techniques}

In pre-prosecution, the Public Prosecutor sometimes faces constraints. This is very likely to happen because at this stage it involves at least 2 (two) Law Enforcement Officials, namely Investigators and Public Prosecutors.

In the case of narcotics crimes that are revealed through undercover buy techniques, the Public Prosecutor needs to be careful in examining the file. This is considering that the undercover buy technique is one of the investigative actions which in this case is carried out by the Police Investigator.

The undercover buy technique in the case mentioned above is carried out by an assistant investigator. If we look at the provisions of Article 79 of the Law on Narcotics which states that the undercover buy investigation technique as referred to in Article 75 letter $\mathrm{j}$ is carried out by the Investigator on a written order from the leader. So the basic authority of the assistant investigator in carrying out undercover buy techniques should be the attention of the Public Prosecutor.

It should be remembered that what the Public Prosecutor needs to examine is the case file submitted by the Investigator (first stage) the completeness of the file, which consists of: ${ }^{11}$

a. formal completeness, means completeness of the judicial administration contained in each case file; and

b. material completeness, is a material act carried out by the suspect, which may include: facts committed by the suspect; elements of criminal acts from material acts committed; the manner in which the crime was committed; and the time and place of the crime being committed.

Referring to the completeness of the files above, the Public Prosecutor was not careful in checking the formal and material completeness. In this case, Bambang Waluyo called the constraints or weaknesses in the implementation of this kind of pre-prosecution as a weakness in juridical technical mastery, namely since the receipt of the P-16 the Public Prosecutor has not studied carefully, seriously and has not carried out any activities after receiving a police report containing a brief description of the criminal case. ${ }^{12}$

Furthermore, the constraint faced by the Public Prosecutor in this case was that there were new facts which were discovered during the trial. This fact is not revealed in the minutes of examination of witnesses and suspects in the case file.

The statements of witnesses and suspects in the case file should explain the series of legal events completely so that all the formulations of the articles are fulfilled, it can be seen that there was an error on the part of the perpetrator and can find out that there are things that can eliminate the criminal offense of the perpetrator. If the series of actions in the minutes of examination of both the witness and the suspect are incomplete, it will result in the trial of new facts that will be revealed that completes the series of actions.

The new fact can strengthen the evidence, but it is possible that the new fact is the reason for the abolition of the crime so that the defendant is not attached to criminal responsibility and therefore cannot be punished, this is as happened in the $a$ quo case.

Minutes of Examination from Investigators in the first stage which can be said to be "perfect" regarding the existence of a criminal act of illicit Narcotics by the perpetrator. Therefore, the Public Prosecutor cannot discover the real facts that the perpetrator is an informant or snitcher from one of the investigators who made the arrest.

The fact that the suspect arrested by investigators was an informant or snitcher used by one of the investigators in uncovering criminal acts of narcotics abuse was only revealed in court. This information is not included in the minutes of examination of both the witness and the suspect in the case file.

This is because the Public Prosecutor only focuses on the information on the minutes of examination of witnesses and suspects related to the fulfillment of the elements of narcotics crime suspected by the investigators, but does not pay attention to the possibility of the reason for the abolition of the crime.

\footnotetext{
${ }^{10}$ See Tangerang District Court Decision Number: 73/Pid.Sus/2019/PN.Tng., page 25.

${ }^{11}$ Suharto Redjomulyo, SH., Penuntutan Dalam Praktek Peradilan, (Jakarta: Sinar Grafika, 2004), page 23.

${ }^{12}$ See Bambang Waluyo, Pidana dan Pemidanaan, (Jakarta: Sinar Grafika, 2008), page 62-63.
} 


\section{Constraints by the Public Prosecutor in Proving Aspects of Criminal Liability for Narcotics Criminals with Undercover Buy Techniques}

The Public Prosecutor does not understand the information he needs in Narcotics crime cases, especially those that use covert buying techniques to avoid prosecution failure. This is a reminder that the Public Prosecutor must be careful of the possibility of the statements of witnesses and suspects being the reason for the abolition of the crime.

This is the function of giving instructions (P-19) as a means for the Public Prosecutor to dig up the statements of witnesses and suspects. The Public Prosecutor must ensure that all evidence that will be presented in court can prove the suspect's guilt.

Apart from that, another obstacle is the absence of witness statements that lighten the suspect in the case file. As in the a quo case, the investigator has asked in the minutes of the examination of the suspect and the suspect has stated that he has no witnesses to mitigate his actions. In fact, it turned out that the suspect had mitigating witnesses and was presented at the trial. These witnesses gave several different statements from the witnesses in the case file.

According to the researcher, it is important for the Public Prosecutor to know the statements of witnesses from two different sides since the pre-prosecution stage. The Public Prosecutor will be ready to face conflicting statements that will appear in court because he has prepared evidence that will be presented to strengthen his indictment.

Regarding the new facts regarding the Defendant, it turned out to be an informant from one of the police officers' witnesses, the obstacle faced by the Public Prosecutor was that there were no regulations that explicitly regulated informants. This is illustrated where in the a quo case the Panel of Judges in their consideration, uses Article 100 of the Law on Narcotics which expressly states that Witnesses, Reporters, Investigators, Public Prosecutors, and Judges who examine cases of Narcotics crime and Narcotics Precursors and their families must be given protection by the state from threats that endanger themselves, their lives, and/or their property, both before, during and after the case examination process, as the legal basis for the Defendant as an informant.

With the lack of regulations regarding informants, various questions related to informants arise, starting from how the criteria for a person can be appointed as an informant, how it works, what is the legal basis for him as an informant, what benefits he/she gets as an informant, or whether there are exceptions for the informant if he commits a crime. because of his services as an informant. The Public Prosecutor will find it difficult to prove whether at the time of the legal event that occurred, the Defendant was a valid informant as stipulated in the applicable regulations while there were no detailed legal regulations regarding informants. This has become a constraint for the Public Prosecutor to prove the perpetrator's guilt.

Based on the description above, the constraints faced by the Public Prosecutor came from their own internal factors. However, when viewed from another perspective (from the investigator's side), the investigator in this case did not provide actual information regarding the completeness of the material submitted at the time of the first stage of dossier submission. As mentioned above regarding the completeness of the material previously, one of which is the facts committed by the perpetrator or suspect. Based on the case example, the suspect arrested by the investigator is an informant or snitcher used by one of the investigators in uncovering the crime of narcotics abuse.

That is, based on the provisions of Article 100 of the Law on Narcotics, the perpetrators should have received protection, not even been arrested as perpetrators of narcotics crimes.

\section{CONCLUSIONS}

The constraints faced by the Public Prosecutor in proving the aspects of criminal responsibility for the perpetrators of narcotics crimes which were revealed by using an undercover buy, among others: There are no clear legal rules regarding the authority of assistant investigators in carrying out their duties related to the undercover buy of narcotics crime ; and the absence of clear legal rules regarding informants and explanations for the implementation of undercover buy techniques known in Narcotics crime. Therefore, the Public Prosecutor must be careful in examining the narcotics crime case files that use undercover buy techniques to avoid prosecution failures

\section{REFERENCES}

1) Andita Rizkianto, Peran Jaksa Dalam Penanganan Pelaku Tindak Pidana Narkotika (Studi Kasus Penyalahgunaan Narkotika Golongan I Yang Ditangani Oleh Kejaksaan Negeri Kota Semarang, (Jurnal Hukum Khaira Ummah Vol. 12. No. 3 September 2017).

2) Bambang Waluyo. 2008. Pidana dan Pemidanaan,.Sinar Grafika. Jakarta.

3) Dhani Catra Nugraha, Pembelian Terselubung (Undercover Buy) sebagai strategi pengungkapan kejahatan Narkoba (Studi Yuridis-Empiris di Kota Pontianak, (Jurnal Nestor Magister Hukum, 2016).

4) Maria S.W. Sumardjono. 2014. Bahan Kuliah Metodologi Penelitian Ilmu Hukum. Universitas Gadjah Mada. Yogyakarta.

5) Peter Mahmud Marzuki. 2013. Penelitian Hukum: Edisi Revisi. Kencana. Jakarta. 
Constraints by the Public Prosecutor in Proving Aspects of Criminal Liability for Narcotics Criminals with Undercover Buy Techniques

6) Sapto Winengku dan Umar Ma'ruf, Teknik Pembelian Terselubung Dalam Penyidikan Tindak Pidana Narkotika (Jurnal Hukum Khaira Ummah Vol. 12 No.4 Desember 2017).

7) Suharto Redjomulyo, SH. 2004. Penuntutan Dalam Praktek Peradilan. Sinar Grafika. Jakarta.

8) Kitab Undang-Undang Hukum Pidana

9) Kitab Undang-Undang Hukum Acara Pidana

10) Law Number 35 of 2009 on the Narcotics

11) Putusan Pengadilan Negeri Tangerang Nomor: 73/Pid.Sus/2019/PN.Tng. 